\title{
CONF-850995. 1
}

To be presented at the Naterials Research Society Nineth International

Symposium on the Scientific Basis of Nhelear Waste Management, Stockholm, Sweden, September 9-12, 1985.

OCEAN FLOOR SEDIMENT AS A REPOSITORY BARRIER: COMPARATIVE DIFFUSION DATA FOR SELECTED RADIONUCLIDES IN SEDIMENTS BROM THE ATLANTIC AND PACIFIC OCEANS*

F. SCAREINER, C. SABAU, A. FRIEDMAN, and S: PRIED

Chezistry Division, Argonne National Laboratory, Argonne, IL 60439, USA

\section{AESTRACT}

Effective diffusion coefficlents for selected radtonuclides have been measured in ocean floor sedinents to provide data for the assessment of barrier effectiveness in subseabed repositories for nuclear waste. The sedinents tested include illite-rich and smectite-rlch red clays from the nid-plate gyre region of the Pacific Ocean, reducing sediment from the continental shelf of the northwest coast of North America, and Atlantic Dcean sediments fron the Southern Nares Abyssal Plain and the Great Meteor East region. Results show extremely small effective diffusion coefflctents with values less than $10^{-14} \mathrm{~m}^{2} \mathrm{~s}^{-1}$ for plutoniun, americium, curiun, thoriun, and tin. Radionuclides with high diffusion coefficients of approximately $10^{-10} \mathrm{~m}^{2} \mathrm{~s}^{-1}$ include the anionic species pertechnetate, $\mathrm{TeO}_{4}^{-}$. Lodide, $\mathrm{I}^{-}$, and selenite, $\mathrm{SeO}_{3}{ }^{-2}$. Uranyl(VI) and neptunyl(V) Ions, which are stable in solution, have diffuston coefficlents around $10^{-12} \mathrm{~m}^{2} \mathrm{~s}^{-1}$. The diffusion behavior of nost radionuclides is similar in the oxygenated Facific sedinents and in the anoxic sedinents from the Atlantic. An exception is neptunium, which is Imoblilzed by Great Meteor East sediment, but has high wobllity in Southern Nares Abyssal Plain sediment. Under stagnant conditions a 30 thick sediment layer form in effective geologic barrier lsoloting radionuclides in a subseabed repository fron the blosphere.

\section{INTROVUCTIOH}

The posstbility of lsolating high-level nuclear waste in the sedtment overlying the base rock of the deep oceans has been the subject of research for wore than a decade.t An obvious advantage of subseabed disposal of nuclear waste ts the fact that the $60 \%$ of the earth's surface covered by water need no longer be excluded in the search for a potential repository site. Furtherwore, geologically stable sedinent formations can be found in the central reglons of ajor oceans that are poor in resources and are long distances away from populated land areas. Bstablishnent of a repository at great depth would not interfere with the sole normal conmercial use of these regions of the sea, which is navigation.

The ongoing effort of U. S. Subseabed Disposal Progran is alwed at the demunstration of the appropriateness and practlcallty of the subseabed disposal concept. 2 In a subseabed repository the waste, contained in

\footnotetext{
Work perforned under the ausptces of Sandia National Laboratories con-
} tract number 25-5644. 
disposal concept. 2 In a subseabed repository the waste, contalred in suitable canisters, will be embedded in the sedinent at a depth no less than 30 melow the surface. This feature sets the subseabed disposal concept off against the practice of "dunping", which Involves placenent of the waste material on top of the sediment at the botton of the water coluan. Such duaping contravenes international convention. ${ }^{3}$

The wate in a subseabed repository will be contalned in canisters that weet the requirenent of maintaining their integrity for 1000 years, which has been set for land-based repositories. 4 However, in the watersaturated environment of the ocean floor sediment corrosion will take place and will ultimately expose the waste ford to leaching. Then thts happens, the sediment overlying the repository nust be relied upon to isolate the radioactive material from the blosphere. It is therefore Important to demonstrate the effectiveness of the sediment as an adequate geologic barrier.

In a nubber of previous reports the results of diffusion tests with selected important radionuclides in several types of sediments from the ald-plate gyre region of the Pacific Ocean have been described.5 In the present paper, new data obtained in two types of sedisent from the Atlantic ncean are added and compared with the earlier results. As will be shown in the following sectlons, all existing data polnt to the sedisent colum as belng a thoroughly effective barrler for the wost hazardous transuraniun elements plutonfun and anericlum, and an adequate mediun for the reduction of radionuclide release even in cases of wre mobile species, such as technetiun and neptuniua.

\section{EXPERIMENTAL}

The laboratory diffusion tests described here were carrled out with five difierent types of sediments, two from the Atlantic Ocean and three from the Pacific. The Atlantic Ocean sediments w11l be referred to as SNAP and GE to indicate thelr respective origins, the Southern Nares Abyssal Plain, and the Great Meteor East location*. The SNAP sediment was obtalned fron a core taken at a point $22^{\circ} 54.1^{\prime} \mathrm{N}$ and $63^{\circ} 29.4^{\prime} \mathrm{W}$. It cons1sted shiefly of clay minerals (70-90\%) and sand, with winor components of calciur carbonate $(1-5 \%)$ and organic carbon $(0.3 \%)$. The GME sediwent cane from a point $30^{\circ} 40.9^{\prime} \mathrm{N}$ and $24^{\circ} 58.9^{\prime} W$. Its composition was 45$50 z$ calclua carbonate, 10-30z clay, 10-30z sand, and 1-1.5z organic carbon.

The three sediwents from the Pacific Ocean included two types of red clays, and a reducing sedisent. The red clays wers collected in the Pactfic MPG I atudy area, which is centered about a point $31^{\circ} 30^{\prime} \mathrm{N}$ and $158^{\circ} \% .6$. These sedicents are not reducing in nature. They are ade up of a mixture of clay unerals, hydrous oxides of Iron and magnesium, and

*Samples of the Atlantlc Ocean sedinents were supplied courtesy of Dr. 'R. E. Cranston, NEA Seabed Worktng Group: Atlantic Geosclence Centre, Bedford Institute of Oceanography, Dartmouth, Nova Scot1a, Canada. 


\section{DISCLAIMER}

This report was prepared as an account of work sponsored by an agency of the United States Government. Neither the United States Government sor any agency thereof, nor any of their employees, makes any warranty, express or implied, or assumes any legal liability or responsibility for the accuracy, completeness, or usefulness of any information, apparatus, product, or process disclosed, or represents that its use would not infringe privately owned rights. Reference herein to any specinic commercial product, process, or service by trade name, trademark, manufucturer, or otherwise does not necesuarily constitute or imply its endorsement, recommendation, or favoring by the United States Government or any agency thereof. The views and opinions of authors expressed herein do not nesessurily state or reflect those of the United States Government or any agency thereof. 
sea water. For the diffusion experiments a sediwent containing the clay aneral 1llite, and one containing swectite were selected. These aterials will be referred to as "Paclfic snectite" and "Pacific 1lite", respectively. A detalled atneralogical description of the red clays from MPG I can be found in reference 6.

The reducing sediment fron the Pacific stemed fron the shelf off the northwest coast of the United States. The reducling quallty is attributed to blological activity, leading to the presence of organic carbon, sulfides and ferrous iron.

In order to preserve a reducing environwent during sample handling and storage, the Atlantic Ocean sediments and the Paciflc reducing sediment were handled in an atwosphere of nitrogen frow which oxygen was excluded to the extent that the oxygen content never exceeded 50 parts per nilition $(0.00005$ ata).

The experiwental technique applied to the determination of effective diffusion coefficlents for tracer radionuclides in the sediment has been described in a previous publication.? The movement by diffusion of substances dissolved in the interstitial sea water of the sedinent follows Flck's law. Since the diffusing specles are present at very low concentrations, the diffusion coefficlent has a constant value. The numbers obtained frow concentration curves observed in the bulk sediment, however, are not directly comparable to self-diffusion coefficients weasured in homogeneous solution. In the two-phase systen of the sedinent the actual distance traveled by dissolved spectes in the. Interstitial channels is larger than the outside masurement of distance indicates. Both, the effects of tortuosity of diffusion path, and the extrene narrowness of the channels, will in general slow the rate of diffusion. Furtherwore, sorptive Interaction of dissolved lons with the solid aineral phases, generally expressed by distribution coefficients, $K_{d}$, has a profound influence on the diffusion process. 8 To indicate that the coefficients reported here include the rate-reducing effects of tortuosity, channel -1ze, and corption, they are referred to as "effective" diffusion coefficlents. These numbers, however, are descrlptive of the overall diffusive spreading of the radionuclides, and can therefore be used for the assesswent of the barrier effectiveness of the sediment.

The effective diffusion coefficlents are evaluated from concentration-distance curves determined experimentally. A schematic representation of the technique is shown in Fig. 1. The diffusion samples are In the shape of small right cylinders with a volune of $2 \mathrm{~cm}^{3}$ each. They are prepared by joining two equal-sized sections of the sediment Intimately at a plane cross-section (No. 1 in Fig 1). The right-hand half section of the sample contains the appropriate tracer nuclide adalxed in untfor concentration, $c_{0}$. Samples of this type ace conveniently ade up In plastic disposable syringes of $10 \mathrm{~cm}^{3}$ volume, the tips of which have been cut off. The plungers serve as a practical means of controlling sediwent volume during preparation. 


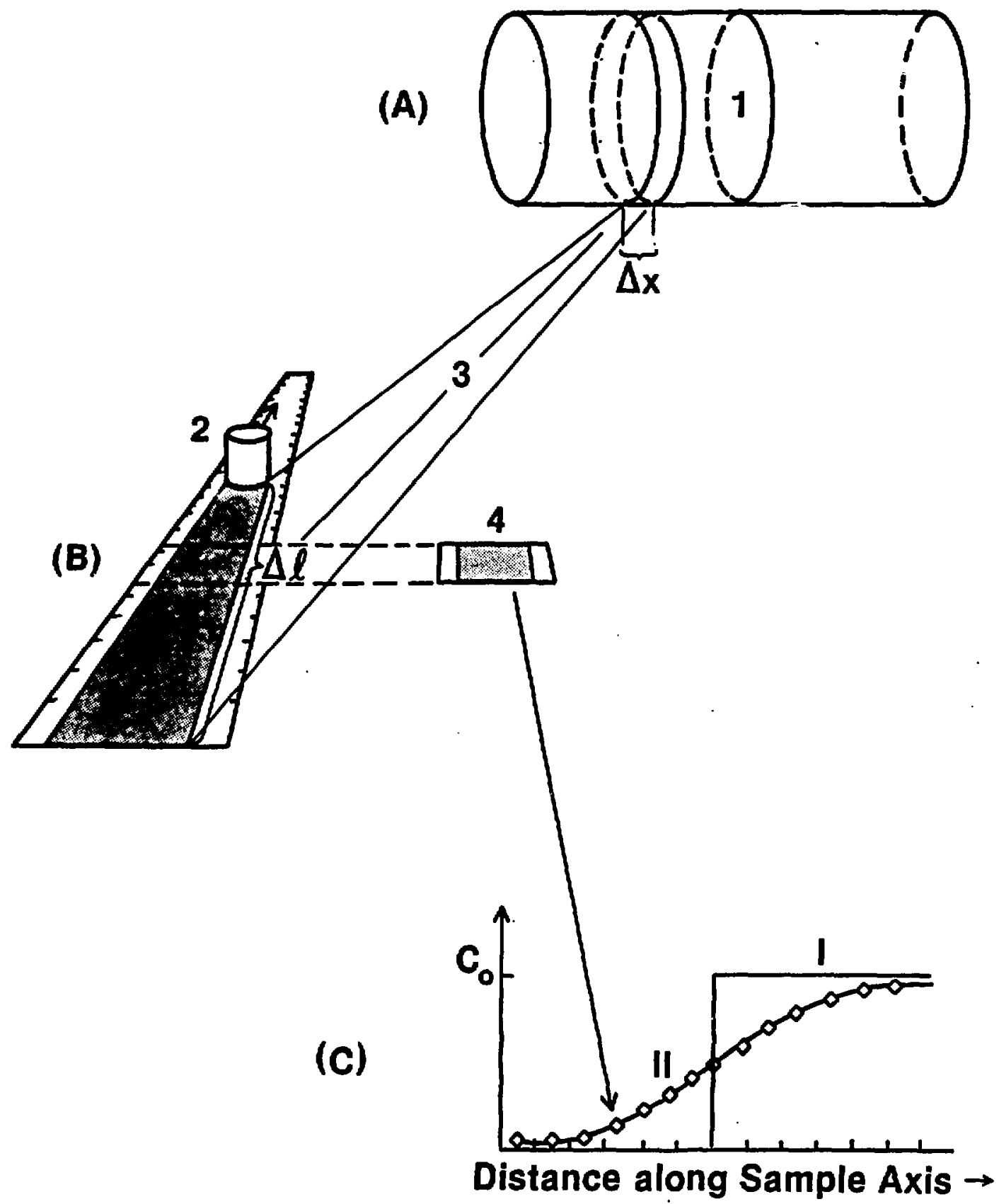

81g. 1. Schenatic representation of the technique used to determine concentration - distance curves and effective diffusion coefficlents. (For an explanation of the numbers refer to the description in the experimental section. "I" and "II" In part C Indicate concentration - distance curves before and after diffusion, respectively.) 
The sanples are stored for appropriate time perlods to pernit diffusion of the tracer nuclides. The concentration-distance function developed during storage tine is deterained by analyzing the activity of the radionuclide as a function of distance. measured along the axis of the sample cylinder. This is achleved by saearing the sedinent in crayon-1ike fashion on long strips of filter paper impregnated with a binder solution (No. 2 of $\mathrm{PIg}$. 1). A section of thickness $\Delta x$ results in s sediment streak of length $\Delta 1$, In which the distance along the paper strip is correlated to the distance in the sanple (No. 3 in F1g. 1). The strips are divided lnto suall sections for assay of activity, each section glelding a data point on the concentration-distance curve (No. 4 and part C, F1g. 1). Specific activities on a relative scale are established by obtaining the amount of sediment on a paper section conductometrically.

Desirable isotopes for these tracer diffusion experiments are those whose decay is associated with the emission of gamm or X-radiation, and whose half-lives are in the 2 month to 2 year range. This cholce eliminates the need for chemical lsolation of the radionuclide from the sediment before assay, since the electromagnetic radiation is not significantly attenuated by the sample material and can be measured with scintillation counting equipment.

\section{RESULTS}

A sumary listing of effective diffusion coefficlents for eleven different radionuclides in sediments from the Atlantic as well as from the Pacific Ocean is given in Table I. The numbers in the last column of the table were obtalned from the observed varlation of the radionuclide concentration with distance after allowing diffusion to occur. Specific activities of the tracer nuclides in the Individual samples were evaluated as described in the preceding section, and plotted versus distance. Typlcal plots of this type are shown in Figs. 2, 3, and 4.

The varlation of the concentration with distance in cylindrical samples of the geometry chosen for the diffusion experiments can be calculated from the solution of the diffusion equation for the case of linear bounded diffusion at a given value of the product of diffusion coefficient and time, D.t. 9 This solution is in the form of a series given by:

$$
\begin{gathered}
\frac{C}{C o}=0.5+\frac{2}{\pi} \sum_{n=1}^{\infty}\left\{\frac{1}{2 \pi-1} \exp \left[-D \cdot t\left(\frac{(2 n-1) \pi}{h}\right)^{2}\right] \cdot\right. \\
\left.\left[\cos (2 n-1) \pi \cdot\left(1-\frac{x}{h}\right)\right] \sin \left[\frac{(2 n-1)}{2} \pi\right]\right\}
\end{gathered}
$$

The best value of $D \cdot t$ in a particular case was determined by numerical computation of the function $\mathrm{Eq} .1$, and by varying the product D.t Incrementally until the minimum value for the varlance of the experimental data points was obtalned.

Figure 2, which shows the experimental data for the diffusion of pertechnetate in Atlantic SNAP sediment after a diffusion time of 2.05 hours, 
TABLE I. Effective Diffusion Coefficlents of Selected Radionuclides in Sediwents fron the Atlantic and Pacific Oceans.

\begin{tabular}{llll}
\hline Nuclide Sediment & No. of & Time & Effective \\
& Samples & $(d=$ days $)$ & Diffusion \\
& $(h=$ hours $)$ & Coefficient \\
& & $D_{\text {eff }} / \mathrm{m}^{2} \mathrm{~s}^{-1}$
\end{tabular}

\begin{tabular}{lllll}
\hline${ }^{237} \mathrm{Pu}$ & Atlantic SNAP & 3 & $60.82 \mathrm{~d}$ & $<1.8 .10^{-14}$ \\
(PuC1 $_{4}$, & Atlantic GME & 3 & $60.85 \mathrm{~d}$ & $<1.6 .10^{-14}$ \\
ox.st. +4$)$ & Pactfic smectite & 4 & $53.7 \mathrm{~d}$ & $<1.0 .10^{-14}$ \\
& Paclfic 1111te & 6 & $119.9 \mathrm{~d}$ & $<1.2 .10^{-14}$
\end{tabular}

${ }^{237} \mathrm{Pu}$

Paciflc smectite $160.0 \mathrm{~d}$

$<1.9 \cdot 10^{-15}$

ox. st. +6)

$\begin{array}{lllll}241 \mathrm{Am} & \text { Atlantic SMAP } & 3 & 71.95 \mathrm{~d} & <8.0 \cdot 10^{-14} \\ \text { AuCl }_{3}, & \text { Atlantic GME } & 3 & 71.98 \mathrm{~d} & <1.2 .10^{-14} \\ \text { ox.st. +3) } & \text { Pacific smectite } & 1 & 35.9 \mathrm{~d} & <1.0 .10^{-14} \\ & \text { Pacific 1111te } & 2 & 240.1 \mathrm{~d} & <1.0 .10^{-14}\end{array}$

\begin{tabular}{|c|c|c|c|c|}
\hline${ }^{235} \mathrm{~Np}$, & Atlantic SNAP & 4 & $53.02 d$ & $(3.3 \pm 1.7) \cdot 10^{-12 b}$ \\
\hline $237 \mathrm{~Np}$ & Atlantlc GME & .4 & $53.05 \mathrm{~d}$ & $<1.9 \cdot 10^{-14}$ \\
\hline$\left(\mathrm{NpO}_{2} \mathrm{Cl}\right.$ & Pacific smectite & 2 & $46.2 d$ & $(2.0 \pm 1.2) \cdot 10^{-12}$ \\
\hline ox.st. +5) & Pacific reducing & 2 & $556.2 d$ & $(1.4 \pm 1.2) \cdot 10^{-12}$ \\
\hline${ }^{243} \mathrm{Cm}_{\mathrm{Km}}$ & Atlantic SNAP & 3 & $108.0 \mathrm{~d}$ & $<1.0 \cdot 10^{-14}$ \\
\hline$\left(\mathrm{CaCl}_{3}\right.$, & Atlantic GME & 3 & $108.0 \mathrm{~d}$ & $<1.0 \cdot 10^{-14}$ \\
\hline ox.st. +3) & Paciflc smectite & 2 & $47.9 d$ & $<2.2 \cdot 10^{-15}$ \\
\hline $95 \mathrm{~m}_{\mathrm{TC}}$ & Atlantic SNAP & 4 & $9.3 \mathrm{~d}$ & $(3.2 \pm 1.5) \cdot 10^{-11}$ \\
\hline$\left(\mathrm{NH}_{4} \mathrm{TcO}_{4}\right.$, & Atlantic GME & 4 & $9.32 d$ & $(2.3 \pm 1.5) \cdot 10^{-11}$ \\
\hline ox.st. +7) & Pacific smectite & 2 & $17.4 d$ & $(3.0 \pm 1.5) \cdot 10^{-10}$ \\
\hline & Pacific reducing & 2 & $65.1 d$ & $(3.0 \pm 1.5) \cdot 10^{-10}$ \\
\hline${ }^{99} \mathrm{TC}$ & Pactflc reducing & 2 & $231.2 d$ & $(3.0 \pm 1.5) \cdot 10^{-10^{c}}$ \\
\hline
\end{tabular}


TABLE I. Continued.

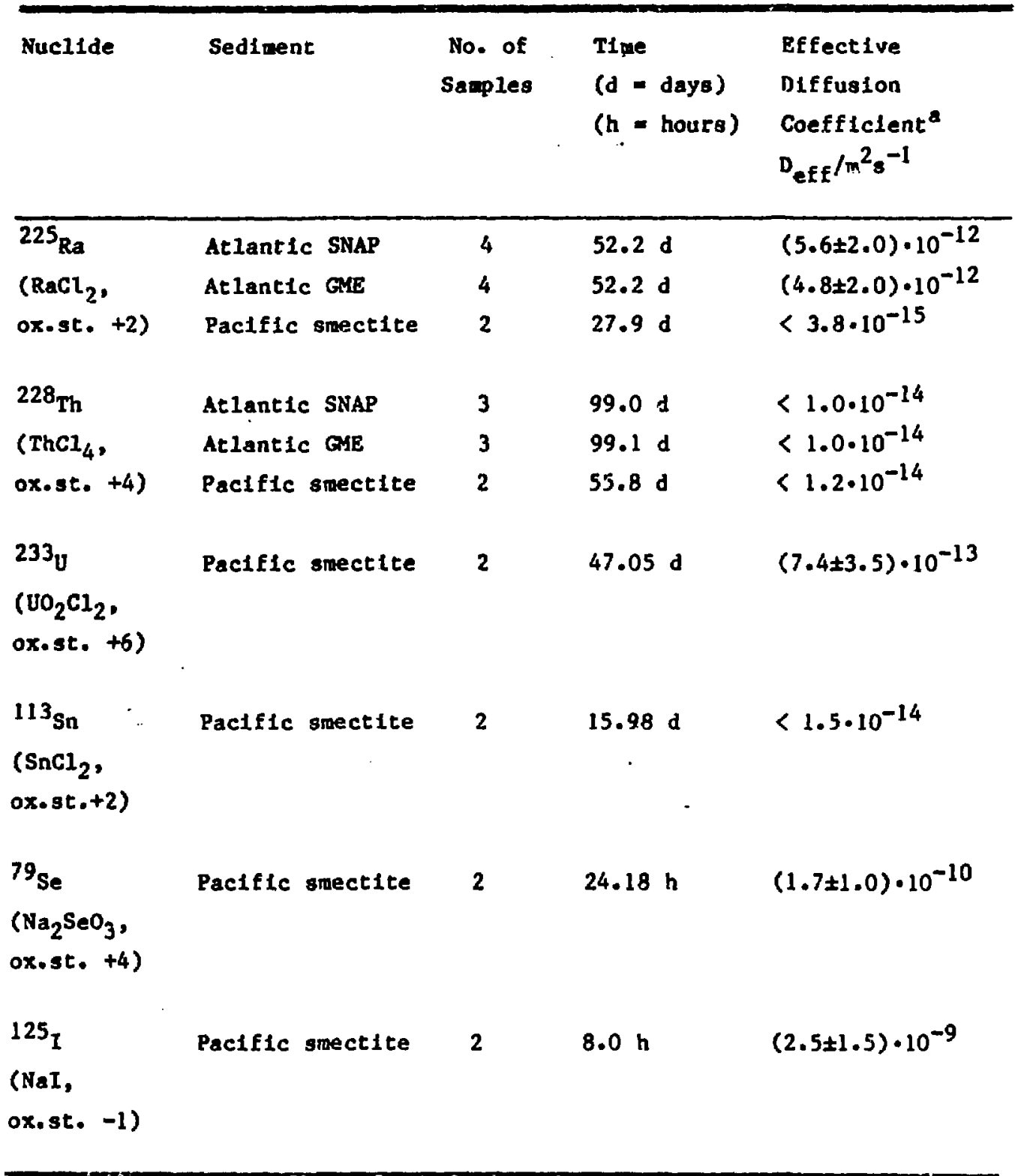

- Values preceded by the "<" sign are upper limits for the effective diffusion coeficient.

b There is some evidence that the neptuniun is Immobilized after an Initial period of diffusion. The coefficient listed characterizes the moblitty during the Initial phase of diffuston.

c The long tern technetium sample indicated complete equilibration of the tracer throughout the sample. The coefficlent listed was derived from short-term experiments. 


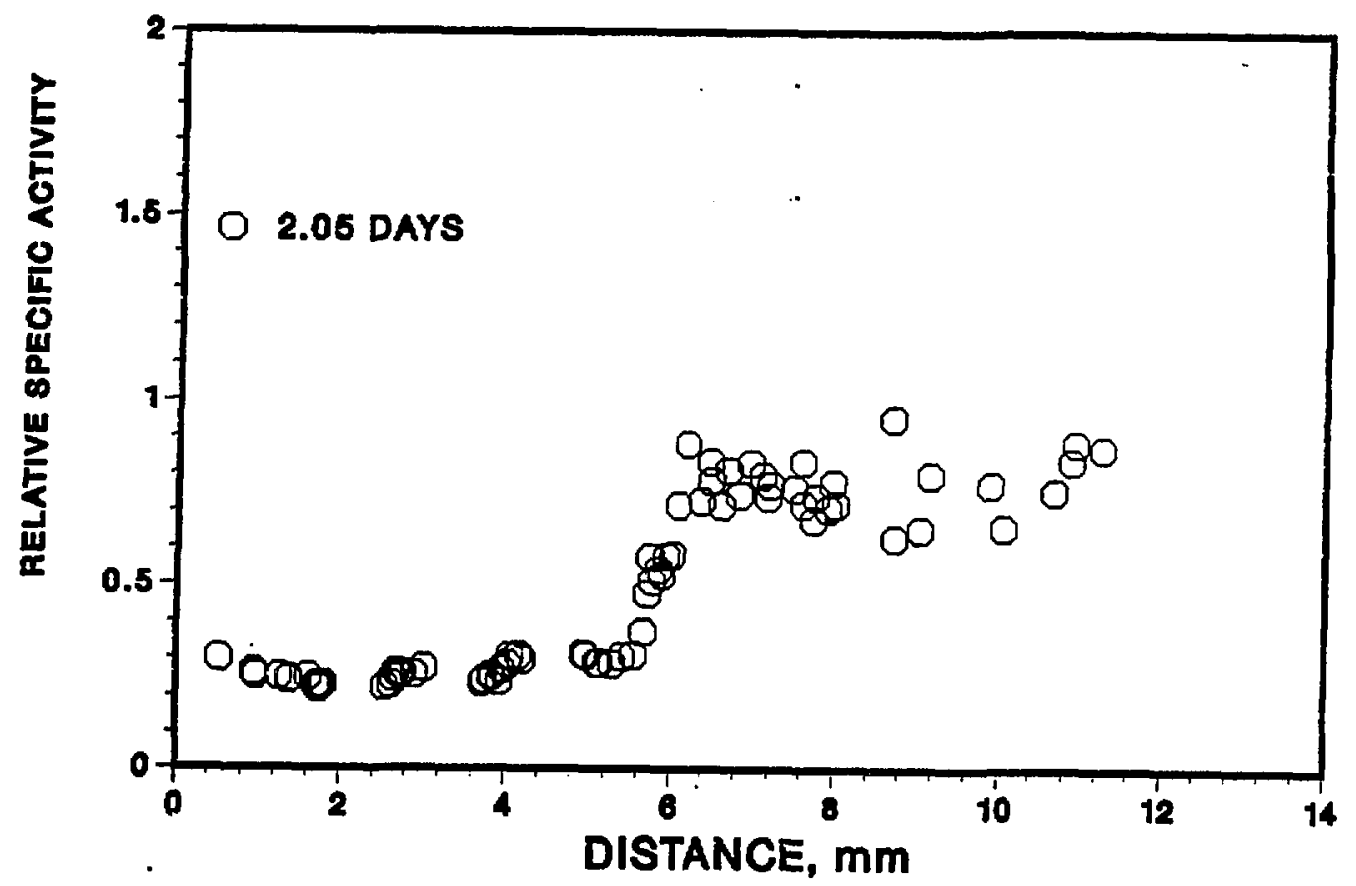

81g. 2. Concentration curve of ${ }^{99} \mathrm{Tc}$ after 2.05 days of diffusion in Atlantic SNAP sediment.

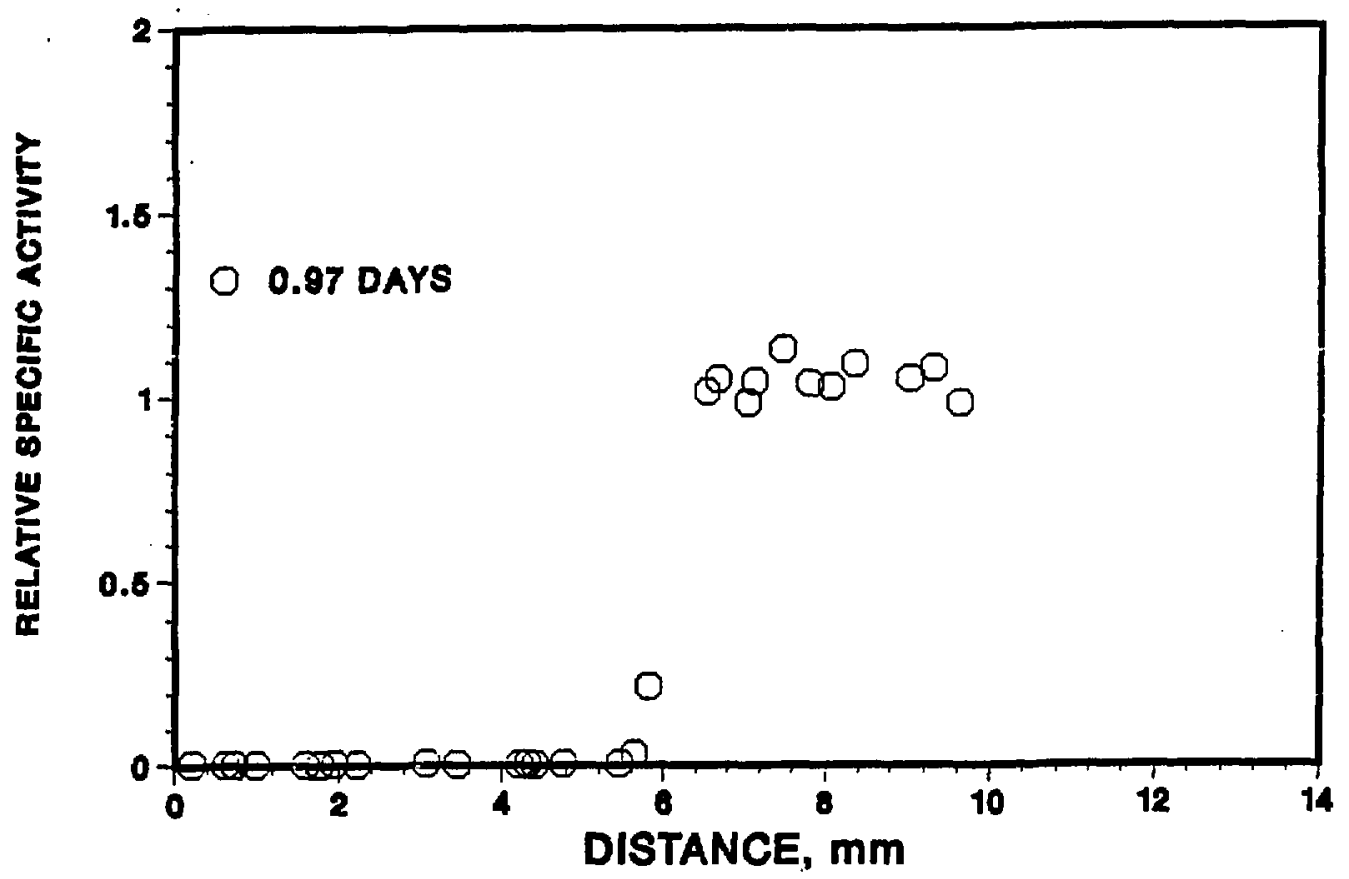

F1g. 3. Concentration curve of ${ }^{237} \mathrm{Pu}$ after 0.97 days of diffusion in Atlantic SNAP pedimenc. 
leads to a best value of $1.010^{-5} \mathrm{n}^{2}$ for D.t. Accordingly, the effective diffusion coefficient of technetiun is $(5.7 \pm 2.8) \cdot 10^{-11} \mathrm{a}^{2} \mathrm{~s}$.

Figures 3 and 4 are plots of experimental activity data for plutonium In Atlantic SNAP sedinent. They can stand as representative for plutonium and amerlcium, as well as other non-moblile specles. The data of Fig. 3 were recorded after 23.3 hours, those of Pig. 4 after 60.8 days. The two concentration-distance curves are equal within experimental error. Diffusion has not progressed as would be expected if F1g. 3 represented a true signoid diffusion profile. The gradual increase of activity measured over approximately a willmeter distance in the center region of the sanple must be attributed to experinental uncertainty. In this case, the value for the effective coefficient of diffusion derived by fitting a curve can only be interpreted as an upper liwiting value. Coefficients that fall into this category are Indicated in Table I by preceding them with a " $<$ " sign. (Conf. footnote a of Table I).

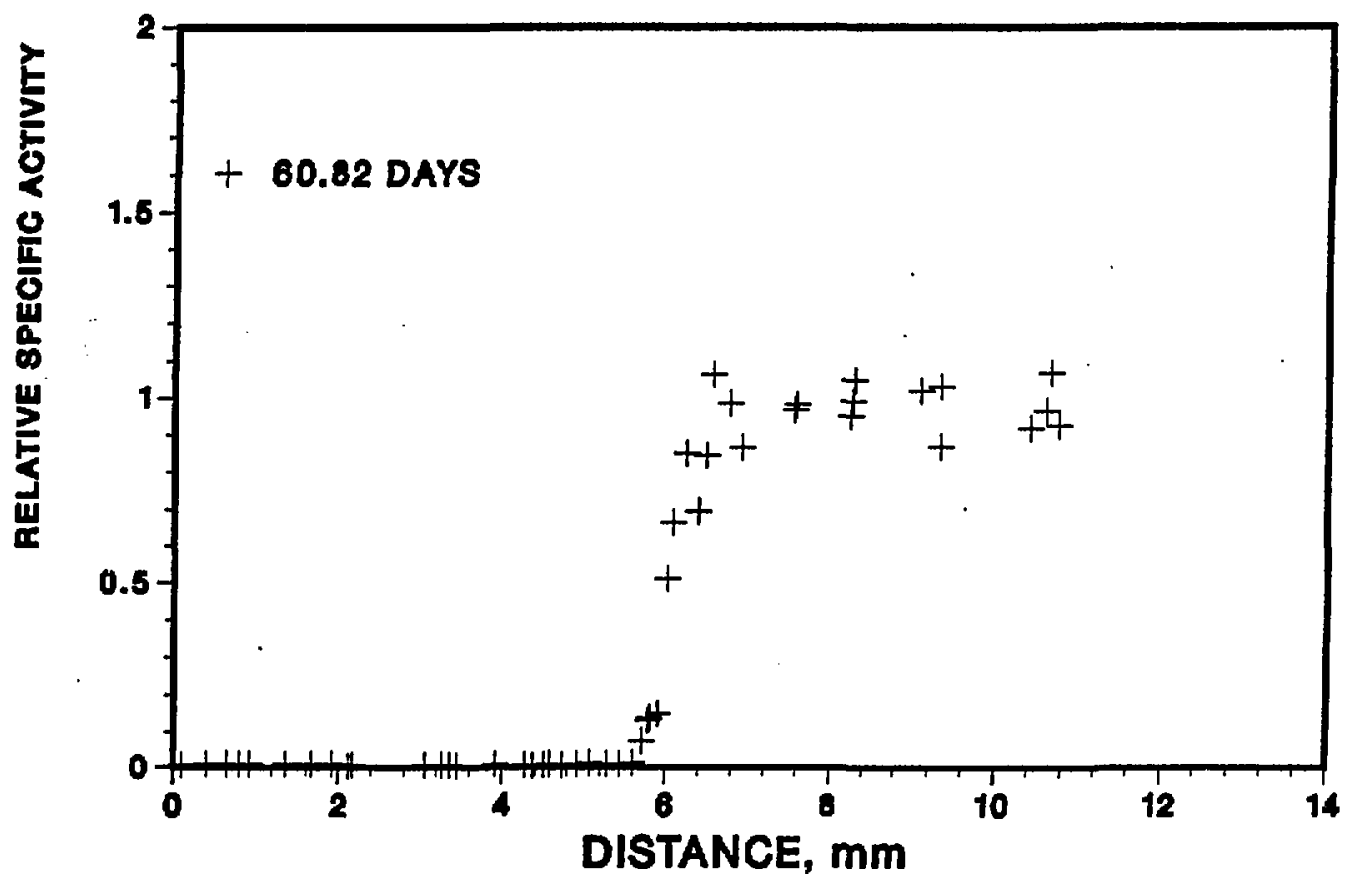

B1g. 4. Concentration curve of ${ }^{237}$ Fu after 60.8 days of diffusion in At lantic SNAP sedinent.

The data 11sted In Table I show the Important transuranium elements plutonium and anericlum to be characterlzed by a very low mobility in all sediments tested. For these two elements no evidence for diffusive spreading in the substrate has been obtalned. Their effective diffusion coefficlents mast therefore be smaller than $1 \cdot 10^{-14}$ to $8 \cdot 10^{-14}$. 
At the other end of the scale of moblilty the antonic specles pertechnetate, lodide, and selenite are found. Their diffusion coefficients are between $10^{-9}$ and $10^{-10^{2}} \mathrm{~m}^{-1}$. This magnitude is consistent with uninhibited diffusion in the interstitial sea water, with an apparent reduction of the nobility because of tortuosity and channel size.

The cationic species $\mathrm{NpO}^{+}$and $\mathrm{UO}_{2}{ }^{+2}$. show clear evidence for diffuston, but at a slower rate than anions. In this case, sorptive interaction with the solid watrix of the clay and hydrous oxides reduces the diffusion rates.

An unexpected result of the diffusion measurements in Atlantic sediwents is observed in the case of neptunium. This element diffuses in the Atlantic SNAP sediment, but is effectively 1 bmobilized in the Atlantic GME sediment. It is possible that the relatively high content of organic carbon In the GIE sediment provides a strong reducing environment in which the pentavalent neptunyl Ion is converted to the tetravalent $\mathrm{Np}^{+4}$ speries, wh1ch 18 hydrolysed to form an insoluble hydioxide. The example of neptunium points to the Importance of site specific studies once a repository site has been selected.

\section{CONCLUSION}

The numbers listed In Table I provide useful guidance in the assessment of the effectiveness of the sediment barrier. Current plans call for an emplacement depth of $30 \mathrm{~m}$ for waste canisters in a subseabed repository. It will be assumed that no upward flow of the interstitial water exists in the sediment overlying the repository, and that the only wode of wovenent for lonic species dissolved in the water is molecular diffulion. The waste canisters will be fabricated to meet the specification set by the U.S. Nuclear Regulatory Commission of retaining their Integrity for at least 1000 years. However, in the seawater-saturated environment of the sediment corrosion cannot be avoided, and ultimately leaching of radionuclides will occur. At that point the sediment layer above the repository becomes the princlpal barrier 1solating the radionuclides from the biosphere.

A simple model can serve to visualize the diffusive spreading of radionuclides through the sediment at rates governed by the effective diffusion coefficients listed in Table $I$. This model assumes the radionuclides initially to be present at a uniform concentration in a sediment layer with a thickness of the expected height of a waste canister, 1.e. $3 \mathrm{~m}$, and that this layer is embedded in radionuclide-free sediment at a depth of 30 m. Diffusion outward from the layer is the well-known case of diffusion from a plane sheet of given thickness. Boundary effects arising from the fact that the repository in not infinite in extent will be ignnred here. Since the repository is very much larger in lateral extension than in thickness, being a square array of perhaps 10000 canisters spaced 10 apart from each other, the approximation by a layer of infinite extent involves only a small error. Besides, the error is on the conservative side, since lateral diffusion diminishes the amount of substance diffusing upward. 
F1gure 5 is a schematic of the model described here. The repository level 1830 m below the sediment surface at the bottom of the ocean. All diffusing radioactive material is initially contained in a 3 m thick layer at the repository level represented by the.rectangular bar. As diffusion progresses, a concentration-distance curve will develop as indicated in Fig. 5. Repository performance for land-based repositories is spectfied In terms of maximum peraissible cumulative releases for the individual radionuclides of concern over a 10000 year perlod, 10 with this in mind, a critical release level can be defined, which determines the distance on the 10000 year concentration-distance curve beyond which no wore than the maxinum permissible amount of a given radionuclide has diffused. In other words, the integral of the curve up to the critical level, Indicated by the cross-hatched area, must represent all the originally embedded material minus the maximum permissible amount released.

For land-based repositorles, 11mits for maximum permissible releases of Individual radionuclides have been set by the U.S. Environmental Protection Agency. 10 For Instance, the cumulative activity permitted to be released over a 10000 year perlod is 100 curles per 1000 tons of waste for ${ }^{239} \mathrm{Pu}$ and 10000 curles per 1000 tons of waste for ${ }^{99} \mathrm{Tc}$. These two elements are at opposite ends of the mobility spectrum with effective diffusion coefficients of $2 \cdot 10^{-14} \mathrm{~m}^{2} \mathrm{~s}^{-1}$ for plutonium and $3 \cdot 10^{-10} \mathrm{~m}^{2} \mathrm{~s}^{-1}$ for technetium.

Fuel removed from reactors typlcally contalns $5.9 \mathrm{~kg}$ of ${ }^{239} \mathrm{Pu}$ and $0.792 \mathrm{~kg}$ of ${ }^{99} \mathrm{Tc}$ per ton of waste. 10 a waste canlster ready for emplacement. In a repository could contain the waste from as much as 3 tons of spent fuel, or a lesser amount if the fuel is not reprocessed ${ }^{11}$. With a spacing of $10 \mathrm{~m}$ between canisters in a square array repository, 1000 tons of fuel require an area of $33300 \mathrm{~m}^{2}$. The activities of ${ }^{239} \mathrm{Pu}$ and ${ }^{99} \mathrm{Tc}$ are 366800 and 13400 curles, respectively.

After a 10000 year period of diffusion all but 100 curies of plutoniun will be contalned below a critical release level that is only $0.3 \mathrm{~m}$ above the level of original emplacement horizon, well within the 30 a thick sediment layer covering the repository. For the more mobile element technetium, the critical level is 3 m above the repository, still confortably below the sediment surface. In this case, the comparatively high fraction of the nuclide that is considered acceptable to be released, alleviates the problem. Other radionuclides are bracketed by these two extrere cases. If diffusion is the only mode by which radioactivity from the waste can spread, the sea.floor sediment provides an adequate geologic barrler for the isolation of nuclear waste.

The simple model calculation does not take into account refinewents, such as the Inclusion of boundary effects of a finite repository, the canister 11fe, and the radinactive decay during diffusion. However, all of these effects reduce the amount of activity diffusing upward from the repository. The Subseabed Disposal Program has developed the computer codes IONMIG and MARINRAD for the comprehensive assessment of radionuclide releases.12,13 Conclusions derived from the elaborate calculations with these codes show that in the long term there are only two nuclides of potential concern in a subseabed repository: technetium and neptunium. 2 


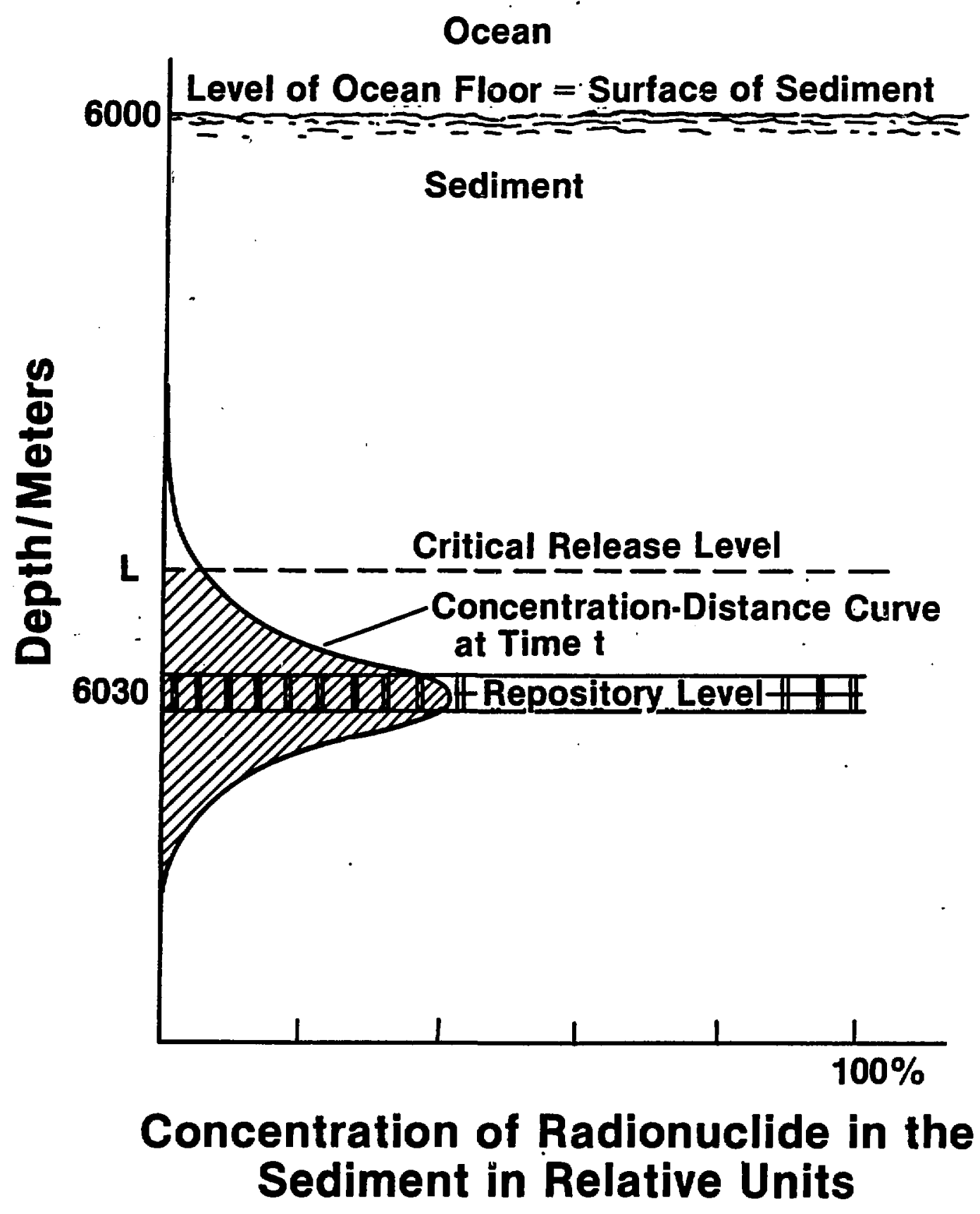

Fig. 5. "Plane sheet" diffusion of radionuclides from a subseabed repository. 
Questions that remain to be addressed In the assesisment of radionuclide algration in ocean floor sedinent coricern the influence of tenperature and pressure on the rate of diffusion. The cenperature in the sed1went 1s near $2^{\circ} \mathrm{C}$ and the pressure 18600 acmospheres. The lower than amblent temperature is likely to reduce the values of effective diffusion coefficients that are neasured at ambient tenperature. The effect of the high pressure, on the other hand, is less easily assessed, and 1ts Influence on diffusion rates wat be measured elther in future laboratory tests, or In situ in the ocean floor.

Final1y, it must be remenbered that the effective diffusion coefficlents are representative for the migration of radionuclides under stagnant conditions. Hydrodynanic flow through the sedinent in an upward direction would easily overwhelm the slow rates of wolecular diffusion and becone the mot important factor for the transport of radionuclides. Its absence at the repository site must be assured. Flow rates of 1 cn per year are suffictent to cause concern, and the absence of such low flow rates is quite difficult to verify. Techniques to deal with the problem of interstitial flow in the sediment are under development. Present evidence suggests that there are large regions of sediment-covered ocean floor in which no upward component of flow exists.

\section{REFERENCES}

1. C. D. Hollister, D. R. Anderson, and G. R. Heath, Science 213, 1321 (1981).

2. "The Subseabed Disposal Progran: 1983 Status Report", Sandia Report. SAND83-1387, Sandia National Laboratorles, Albuquerque, New Mexico, 1983, NIS.*

3. "Convention on the Prevention of Marine Pollution by Dumping of Wastes and Other Matter" In International Legal Materials 11,1291 (1972).

4. Federal Register 46,35289 (1981).

5. a) F. Schrelner, S. Fried, and A. Frledaan, Nuclear Technology 59, 429 (1982).

b) F. Schrelner, S.' Fried, and A. Friednan in "Subseabed Annuai Report, Chenical Response Studies, October 1981 - Septenber 1982", Sand1a Report SAND82-2713, page 239, NTIS.*

c) F. Schreiner, S. Fried, and A. Friedman In "Subseabed Annual Report, Chemical Response Studies, October 1982 - Septenber 1983", Sandia Report, in press.

d) F. Schreiner and C. Sabau In "Subseabed Annual Report, Chemical Response Studies, October 1983 - September 1984", Sandia Report, In press.

6. "Subseabed Disposal Prograw - A First Year Report", W. Bishop, ed., Sand1a Report SAND74-0410, NTIS.*

7. P. Schrelner, S. Fried, and A. Friedman, Nuclear Technology 59, 429 (1982).

8. R. A. Berner, Earth and Planetary Sclences Letters 29, 33 (1976). 
9. "The Mathenatics of Diffusion", by J. Crank, 2nd edition, Clarendon Press, Oxford, 1975.

10. Managing the Nation's Comerclal High-Level Radioactive Waste" (Hashington, D. C.: U.S. Congress, Office of Technology Assessment, OTA-0-171, March 1985).

11. B. L Cohen, Rev. Mod. Phys. 49, 1 (1977).

12. A. J. Russo, Sandia Report SAND79-1666, Sandia National Laboratorles, Albuquerque, New Mexico, 1980, NTIS.*

13. C. L. Koplik, et al, Sandia Report SAND83-7104, Sandia National laboratories, Albuquerque, New Mexico, 1984, NTIS.*

*Avallable frow the National Techntcal Infermation Service, U. S. Departwent of Commerce, 5285 Port Royal Road, Springfield Virginia 22161, USA. 